Canadian Journal of Higher Education Revue canadienne d'enseignement supérieur

Volume 42, No. 3, 2012, pages 116-142

\title{
Sense of Belonging and First-Year Academic Literacy
}

\author{
Steve Marshall \\ Simon Fraser University \\ Mingming Zhou \\ Nanyang Technological University \\ Ted Gervan \\ Vancouver Film School \\ Sunita Wiebe \\ The Art Institute of Vancouver
}

\begin{abstract}
In this article, we analyze a broad range of factors that affect the sense of belonging of undergraduate students taking a first-year academic literacy course (ALC) at a multicultural, multilingual university in Vancouver, Canada. Students who fail to meet the university's language and literacy requirements are required to pass ALC before they can enrol in writing courses across the disciplines. Consequently, many of those students feel that they have yet to be accepted as fully legitimate members of the university community. We present data from a two-year, mixed-method study, which involved asking students in surveys and interviews about their sense of belonging, as well as analyzing their reflective writing samples for issues related to their sense of belonging. We found that the participants' perceptions of sense of belonging are multilayered and context-dependent, relating to changes in time and space, classroom pedagogy, and other social, cultural, and linguistic factors. Implications for higher education are discussed.
\end{abstract}




\section{RÉSUMÉ}

Dans cet article, nous analysons un grand éventail de facteurs ayant un effet sur le sentiment d'appartenance d'étudiants en première année d'un premier cycle universitaire qui prennent un cours de littératie académique (CLA) dans une université multilingue et multiculturelle de Vancouver, au Canada. Les étudiants qui ne possèdent pas les préalables linguistiques et littéraires exigés en anglais par l'université doivent d'abord réussir un cours CLA avant de s’inscrire aux cours de rédaction des différentes disciplines. Par conséquent, nombre d'entre eux ont le sentiment de ne pas être encore acceptés comme membres légitimes et à part entière de la communauté universitaire. Nous présentons les données d'une étude adoptant des méthodologies mixtes sur une durée de deux ans dans laquelle nous avons demandé à des étudiants, par le biais d'enquêtes et d'entretiens, d'exprimer leur sentiment d'appartenance. Nous avons également analysé des échantillons de leurs réflexions écrites, dans le but de faire émerger des thèmes en lien avec leur sentiment d'appartenance. Nous avons conclu que la perception des participants envers leur sentiment d'appartenance s'échelonnait sur plusieurs niveaux et dépendait du contexte, selon les changements temporels et spatiaux, la pédagogie adoptée en classe et d'autres facteurs linguistiques, culturels et sociaux. Nous examinons aussi les implications de ces résultats pour l'éducation supérieure.

Many factors affect the transition of students from secondary school to the first year of higher education. For some students, this transition is complicated by institutional requirements that oblige them to take foundational or preparatory courses as a prerequisite to registering in certain core first-year and lower-division courses. In such instances, students may feel they are not accepted as legitimate members of the academic community, which may, in turn, affect their sense of belonging to the institution in which they are studying.

In our study, we look at one such case, Pacific Coast University (PCU), where students with a Grade 12 English score of under 75\%, or an International English Language Testing System (IELTS) score of under 6.5 if they are international students with English as an additional language, are required to take a foundational academic literacy course (ALC) during their first year. For such students, ALC is a prerequisite for registering in required lower-division writing in the disciplines courses. ${ }^{1}$

Pacific Coast University is a multicultural, multilingual university located in Metro Vancouver. Between 800 and 900 students a year take ALC. Classes are made up of students from diverse social, cultural, and linguistic backgrounds, and from different disciplines across the university. Most ALC students are multilingual; most arrived as immigrants at some stage during their schooling, whereas some were born in Canada. A minority are international students with English as an additional language and Canadian-born native speakers of English. Despite bringing cultural and linguistic assets to the university, ALC students find themselves enrolled in a course that carries a "remedial ESL identity" (Marshall, 2010), which can cause many of them to question their legitimacy as full members of the academic community. Hence, there is a need for ALC students to develop a sense of belonging, one that allows them to feel accepted and recognized as legitimate and respected 
members of the academic community (Booker, 2006; Goodenow, 1993). Consequently, ALC aims not only to teach foundational academic literacy skills and prepare students for the demands of different forms of university writing across the disciplines, but also to foster sense of belonging in the ALC classroom and the broader university.

In this article, we analyze the factors that affect the sense of belonging of first-year students taking ALC at Pacific Coast University. We present data from a two-year, mixedmethod study that combined online surveys and semi-structured interviews in which participants answered questions about their sense of belonging, and an analysis of students' writing samples for content related to belonging. Our aim in this article is not to measure a correlation between academic literacy competence and the sense of belonging of our participants; nor is it to measure the extent to which the course, as an intervention, succeeds in fostering sense of belonging. Instead, we present a broad portrait of how our participants, taking a course that is positioned institutionally as remedial, develop a sense of belonging to the course itself and to the broader university. In doing so, we provide insights for institutional leaders and educators involved in supporting students during their first year of higher education. We address two questions: What factors affect ALC students' sense of belonging during their first year of study? And, at what micro and macro levels, and in which contexts, do ALC students perceive (or not) sense of belonging?

Our data reveal that our participants' development of sense of belonging during their first year of university is complex, multi-layered, and context-dependent. We highlight multiple factors affecting sense of belonging, ranging from the changing time and space relations that come with making the transition to post-secondary education, to issues related to learning experiences in classrooms. We end by considering the implications of our findings for institutions of higher education. ${ }^{2}$

\section{SENSE OF BELONGING IN HIGHER EDUCATION AND CANADA}

The sense of belonging of university and college students has been the focus of a considerable number of studies in recent years. In broad terms, sense of belonging can be understood as a fundamental human need for individuals to belong, and to be respected and valued members of a group or community of people (Baumeister \& Leary, 1995; Booker, 2006; Bosetti, Kawalilak, \& Patterson, 2008; Freeman, Anderman, \& Jensen, 2007; Goodenow, 1993; Hagerty, Williams, \& Oe, 2002; Johnson, Soldner, Leonard, \& Alvarez, 2007; Sedgwick \& Yonge, 2008). In higher education, the concept of belonging has been analyzed from many perspectives. The evolution of the concept of belonging can be characterized by ongoing tensions between the psychological complexity of the phenomenon and the researchers' ability to develop models that are practical yet gender robust enough to evaluate students' sense of belonging and outcomes in educational settings.

Spady (1970) first focused on the precursory concept of integration in higher education by adapting Durkheim's (1951) social causation theory to create a model for college dropout. Spady's model (1971) has been challenged due to a perceived lack of clarity in the theoretical modelling of social and academic integration (Bollen \& Hoyle, 1990; Hurtado \& Carter, 1997) and its affiliation with Durkheim's theory (Attinasi, 1989). Later, Tinto (1975) developed a model for student withdrawal, which, after many revisions, is still widely referenced today. His theory, however, has also been the subject of criticism as well as theoretical revisions. 
For example, Tinto's (1997) theory of integration de-emphasizes factors that are external to the classroom. His model does not broadly encompass students' contextual or normative fit within the educational environment, or adequately separate students' demonstration of integration (belonging) through their activities and students' subjective or psychological sense of belonging. Although many researchers have found Tinto's theory of integration to be congruent with belonging theories (Hausman, Ward Schofield, \& Woods, 2007; Madgett \& Belanger, 2008), particularly when those theories have been used in analyzing students' decisions to stay at or leave college or university (Hoffman, Richmond, Morrow, \& Salomone, 2003; Kember \& Leung, 2004; Yorke, 2004; Yum, Kember, \& Siaw, 2001), his model is problematic for its use in the investigation of complex psychological processes related to student dropout, such as the impact of belonging on students' social and psychological functioning (Hagerty, Williams, Coyne, \& Early, 1996). Research in the area of organizational behaviour also highlights challenges in terms of evaluating psychological processes, such as individuals' understanding of their compatibility within a social system (Edwards, 1994). In effect, many of these studies underscore theoretical and practical challenges, at the nexus of which are institutionally diverse student populations and the modes of interpreting multi-dimensional social phenomena in research designs (Andres, Andruske, \& Hawkey, 1996; Hurtado \& Carter, 1997; Johnson et al., 2007; Lehmann, 2007; Tucker, 1999).

Evaluating the experiences of students has evolved with the shift from elite to mass education systems which began in the late 20th century (Schuetze \& Slowey, 2002). Student populations have rapidly diversified at the post-secondary level in Canada and globally. The traditional student profile (i.e., students who are 18 to 24 years of age, attend full-time, and reside on campus), as defined by Bean and Metzner (1985), is no longer a valid construct for evaluating phenomena such as belonging and dropout. Extra-institutional factors further complicate research on student outcomes and belonging. However, many empirical studies based on Tinto's model have been theoretically confined to the institution (e.g., Berger \& Braxton, 1998; Pascarella \& Terenzini, 1980) and have viewed academic and social integration as discrete systems, thus precluding the notions of interdependence or interchangeability (Tucker, 1999). Furthermore, these studies do not adequately acknowledge the impact of extra-institutional factors such as social and cultural structures on the complex and multi-dimensional phenomenon that is students' sense of belonging (Andres et al., 1996).

By contrast, many studies have used constructs that emphasize the relationship between normative differences and students' subjective sense of belonging, including factors such as ethnicity (Codjoe, 2005; Hurtado \& Carter, 1997; Johnson et al., 2007; Strayhorn, 2008), social class (Lehmann, 2007; McGee Thompson, 2004; Ostrove \& Long, 2007; Read, Archer, \& Leathwood, 2003), and cultural modes of learning (Campbell \& Li, 2008; Marker, 2004).

Hurtado and Carter (1997) developed a model for sense of belonging that extended beyond Tinto's interactionalist framework to address some of these problematic conceptions, including conceptions of students' assimilation and the preference for objective rather than subjective means of assessing students' integration (that is, belonging). Spady (1971) posited that students' social integration was informed by a social system (the campus) and the sum of its parts. The literature demonstrates that this idea has now been extended to social 
systems outside of the campus as well as overlapping systems. Canadian literature on belonging parallels this theme. Many researchers have adopted paradigms that acknowledge the diversity of students, their contexts and agency within institutions, and the variety of extra-institutional factors at play in the negotiation of their belonging and outcomes.

Andres et al. (1996) recognized that the factors associated with concepts of fit or persistence are seemingly infinite, and they span multiple dimensions including time, space, and social structures (p. 5). In their study of first-year post-secondary life, an action-based research design was purposefully selected to challenge existing theoretical paradigms. By drawing on Giddens's (1984) notion of structure and agency, Andres et al. aimed to more faithfully decipher variables like belonging, retention, and student success. Accordingly, they developed a research model that was more responsive to the dynamic relationship between students' agency and the living structure(s) they inhabit-educational institutions and other social structures outside of the academic community.

Several Canadian studies (Andres et al., 1996; Bosetti et al., 2008; Lehman, 2007) have invoked Bourdieu's closely related notions of habitus, field theory, and gender (Bourdieu, 1990, 1991 as theoretical constructs to assess how a variety of non-traditional student populations, as well as faculty, negotiate their sense of belonging in Canadian post-secondary institutions. For instance, Lehmann (2007) utilized the concept of habitus to explore how working-class university students, who have been traditionally excluded from the university (Axelrod \& Reid, 1989), formulated their sense of belonging in a research-intensive university in Ontario with a relatively affluent student population. Bosetti et al. (2008) drew on habitus, field theory, and gender theory to explore how female faculty members make sense of their professional identity and sense of belonging in a rapidly changing university environment in Alberta. To decipher how the influence of social status in the broader society affected the student achievement of minority francophone, Aboriginal, and African Canadian populations, two studies (Codjoe, 2005; Cummins, 1997) applied Ogbu's $(1978,1992)$ closely related concept of voluntary and involuntary minorities.

Indeed, a small yet important body of Canadian research has explored students' sense of belonging through multi-faceted constructs that embrace notions of time, space, and socio-cultural contexts. Codjoe's study (2005) of African Canadians in Alberta universities and colleges invoked theories of positionality (Banks, 1993, 1995, 1996, 2002) and social reproduction (Bullivant, 1983) to explore how economic, political, and cultural norms were at play in curriculum and instruction. His study asserted how exclusionary curriculum can be detrimental to the experiences, identity, and belonging of minority students attending post-secondary schools in Edmonton. Another study demonstrated how student-mothers' belonging and participation in college were significantly influenced by the dichotomy between experiencing the temporal, social, and value-based realities of motherhood and being student-mothers in a public college institution (McGee Thompson, 2004). Furthermore, Lyakhovetska's (2004) study of international students suggested that participating in class and making friends with domestic students can be problematic for international students from non-English-speaking countries (p. 210). Participants in Lyakhovetska's study engaged at a higher level when the course content involved international matters, particularly those involving their own background contexts.

These developments are of particular relevance to our participants at PCU, who come from diverse social, cultural, and linguistic backgrounds, and who find themselves study- 
ing together in a social system that embodies a remedial and non-mainstream identity. A primary goal of this research is, therefore, to flesh out the complexities in ALC students' sense of belonging within this particular contextual environment.

Our study at PCU follows others that have focused on the participation of non-traditional students (Campbell \& Li, 2008; Clauss-Ehlers \& Wibrowski 2007; Codjoe, 2005; Hurtado \& Carter, 1997; Johnson et al., 2007; Kember, Lee, \& Li, 2001; Kember \& Leung, 2004; Lehmann, 2007; Lyakhovetska, 2004; McGee Thompson, 2004; Ostrove \& Long, 2007; Read et al., 2003; Strayhorn, 2008; Yum et al., 2001) and relates to several studies that have emphasized mixed methods in order to grapple with the complex psychological nature of belonging (Campbell \& Li, 2008; Hoffman et al., 2003; Read et al., 2003; Sedgwick \& Yonge, 2008). An important difference to note, however, in this relationship, is that our mixed-method approach did not employ a combination of quantitative and qualitative research methods in order to achieve validity and identify correlation and causality, but rather the approach resulted in a broad portrait of what we saw as complex, multi-layered, and context-dependent factors affecting our participants' sense of belonging. We deployed data instruments over a period of time and in different learning space (Braxton, Milem, \& Sullivan, 2000; Hausman et al., 2007; Hurtado \& Carter, 1997), thus acknowledging the temporal and contextual aspects of the phenomenon of sense of belonging. In doing so, we emphasize the inextricable link between normative contexts and students' sense of belonging in the educational environment. Furthermore, as in other studies (Campbell \& Li, 2008; Kostogriz \& Tsolidis, 2008; Read et al., 2003), identity is also a prominent theme, as is in-class participation and interaction (Braxton et al., 2000; Freeman et al., 2007; Hoffman et al., 2003; Kember et al., 2001) and academic growth (Moores \& Popadiuk, 2011). ${ }^{3}$ These emergent investigations are particularly relevant to our focus on students' sense of belonging in the contexts of a first-year academic literacy course that carries an institutional identity of remediation and deficit.

\section{METHOD}

\section{Mixed Methods}

In the quantitative part of the study, our aim was to gain insight into ALC students' backgrounds and experiences rather than to measure the success of the course as an "intervention" that could be replicated after correlations were found and variables assessed. The 419 survey respondents were, therefore, not selected through random sampling aimed at gaining a representative sample, but instead the respondents completed optional surveys. Later, all 14 interviewees who responded to an open email call were interviewed, with six also providing writing samples. The qualitative aspect was employed to reveal the multilayered, context-dependent nature of participants' sense of belonging in terms of contextualized behaviour and meanings that continuously evolve (Cohen, Manion, \& Morrison, 2000). The mixed methods took advantage of the strengths of both quantitative and qualitative approaches, enabling us to gain insights (broad cross-sections as well as in-depth analysis) that might be missed through the use of a single approach (Ivankova, Creswell, \& Stick, 2006; Johnson \& Onwuegbuzie, 2004). In this sense, we felt that mixed methods would provide holistic understandings that could also result in better-informed education policies (Davies, 2000; Steckler, McLeroy, Goodman, Bird, \& McCormick, 1992). 


\section{Participants.}

In the broader study, a total of 977 ALC students completed optional online pre- and/ or post-course surveys from spring 2007 to fall 2009 (more details follow below under "Procedure"). The data set in this study only included 419 ALC students who completed either pre- or post-course surveys during the spring and fall semesters of 2007 (see Table 1). These two semesters were chosen because they coincided with the time when interviews (see below) were conducted so that we could compare data from multiple sources. All 419 participants were in their first year of study at PCU. As the sampling was not random, we do not make any claims that this group was representative of the broader student body in ALC or in the university as a whole.

Table 1.

Semesters and Students Included in the Study

\begin{tabular}{lcccc}
\hline Semester & $\begin{array}{c}\text { Student } \\
\text { enrolment }\end{array}$ & $\begin{array}{c}\text { Completed } \\
\text { pre-course survey }\end{array}$ & $\begin{array}{c}\text { Completed } \\
\text { post-course survey }\end{array}$ & Completed both \\
\hline 2007 spring & 121 & 60 & 55 & 20 \\
2007 fall & 298 & 227 & 181 & 101 \\
Total & 419 & 287 & 236 & 121 \\
\hline
\end{tabular}

The mean age of survey participants was 19.8 years $(S D=4.32)$. They were drawn from seven faculties: Arts/Social Science 40\%, Applied Science 25\%, Sciences 15\%, Business Administration 14\%, Health Sciences 4\%, and Undeclared 2\%. For the $75 \%$ of participants in their first semester, pre-course surveys were completed during their first week at university. Participants had diverse linguistic backgrounds: $89 \%$ reported speaking a language other than English, 86\% came from multilingual home environments, and 66\% were able to write in their additional languages. The ethnicities that participants described in surveys were also diverse, with some participants identifying with more than one nationality: Chinese 57\% (including Hong Kong, Taiwan, and Macau), Korean or Japanese $21 \%$, European 8\%, Canadian Caucasian 7\%, Other Asian 10\%, First Nations 2\%, African $2 \%$, and Latin American $2 \%$.

The second set of participants included 14 students who responded to two open email invitations to participate in semi-structured interviews with the primary researcher in the semester following ALC. The 14 interviewees also offered samples of their reflective writing for analysis. Table 2 below lists interviewees' place of birth, age, languages, and origins of parents (if Canadian-born).

\section{Procedure.}

Optional online pre-course surveys were completed during a lab class on the day of the second ALC class, whereas post-course surveys were completed 13 weeks later in the final ALC class. Respondents read a consent form and gave informed consent by continuing with the survey. Participants disclosed their student identification codes for possible cross-referencing between pre- and post-course surveys, and confidentiality was guaran- 
teed. Interviewees were contacted by an open email to ALC students, sent during the second week of the semester following ALC completion. All 14 students who responded were interviewed by the primary researcher. One interview was with three students together, two with two students, and the remainder one-on-one. Interviewees read a consent form and gave informed consent to be interviewed and for their anonymized writing samples to be used for teaching and research.

Table 2.

Demographic Information About 14 Interviewees

\begin{tabular}{|c|c|c|c|c|}
\hline Interviewee (age) & Place of birth & First language & $\begin{array}{l}\text { Additional language } \\
\text { (if applicable) }\end{array}$ & $\begin{array}{l}\text { If Canadian born, } \\
\text { origins of parents }\end{array}$ \\
\hline Amy (24) & Hong Kong & Cantonese & English, Mandarin & Not available \\
\hline Carme (21) & Spain & Catalan & Spanish, English & Not available \\
\hline Ellen (19) & Canada & English & Not available & Canada \\
\hline Emi (18) & Canada & English & Not available & China \& Japan \\
\hline George (22) & Taiwan & Taiwanese & $\begin{array}{l}\text { English, Mandarin, } \\
\text { Japanese }\end{array}$ & Not available \\
\hline Joseph (18) & Canada & Cantonese & English & Hong Kong \\
\hline Julie (18) & Hong Kong & Cantonese & English, Mandarin & Not available \\
\hline Lisa (19) & Hong Kong & Cantonese & English & Not available \\
\hline Marie (19) & Canada & English & Mandarin, French & China \& Japan \\
\hline Monique (19) & Canada & English & Not available & Canada \\
\hline Morris (19) & Canada & Cantonese & English & Hong Kong \\
\hline Soreya (19) & Canada & English & French, Hindi & Fiji \\
\hline Tamsin (19) & China & Mandarin & English & Not available \\
\hline Tony (21) & Canada & English & Not available & Hong Kong \\
\hline
\end{tabular}

\section{Survey Instruments.}

The pre-course survey addressed themes such as cultural and linguistic background, academic background, academic literacy skills in English, and sense of belonging. Question forms included Likert-scale responses from 1 to 5 , yes/no questions with follow-up open responses, and open-response questions. The response rate for pre- and post-course surveys for the two semesters was $69 \%$ and $56 \%$, respectively. Not all respondents answered all of the survey questions; thus, the figures presented are based on different numbers of respondents. In post-course surveys, key questions were repeated, including those related to sense of belonging. For the purposes of this article, we focus on the following pre- and post-course survey questions: "How do you feel about the academic community at PCU? (tick the answer that is closest to describing how you feel) [ ] I feel like I don't belong; [ ] I feel like I belong; [ ] Other: please describe in Question 22 (pre-course) [Question 3 (post-course)]. 


\section{Interviews and writing samples.}

Survey questions were repeated in interviews to build on emerging themes. We recognize that knowledge was co-constructed in different ways in online surveys, with students interacting with an omniscient researcher via a computer screen and online survey program, and in "intersubjective and interactive" interviews (Kvale, 1996, p. 42), where meanings and knowledge are co-constructed between interviewer and interviewee (Cohen, Manion, \& Morrison, 2000; Kvale, 1996). Selected samples of reflective writing done during ALC were analyzed for representations of themes related to sense of belonging. The samples provided are from a narrative reflection on a major event in students' lives and a reflective introduction to end-of-course portfolios. Although data gathered from surveys and interviews were in response to questions that explicitly mentioned sense of belonging, writing samples were narrative reflections on life experience and on experience in ALC, written from instructions with no specific reference to sense of belonging.

\section{Limitations.}

Three limitations should be highlighted before we present our findings. First, participants responded in surveys to questions about sense of belonging without first articulating their understanding of the concept, which could lead to variance across interpretations and influence responses. Second, pre-course surveys were conducted on the second day of the course, and for $25 \%$ of respondents, it was not their first semester at university. Responses may, therefore, have been affected by early experiences in ALC and at the university. Third, interviews were conducted between 8 and 16 weeks after completing the course. The different stages that participants were at in coursework and examination completion will undoubtedly have played a part in how participants understood their sense of belonging in different ways and at different times..

\section{RESULTS}

The data presented in this section are from surveys, interviews, and writing samples. Answers to the survey questions related to sense of belonging were analyzed and coded according to themes, most notably factors affecting students' sense of belonging in the course and to the university as a whole. These same themes were then brought up in interviews and expanded on for further insight. Students' narrative writing and end-of-course written portfolios were then analyzed for representation of the same themes and/or others. Data from the quantitative and qualitative parts of the study are presented under two main themes of sense of belonging that emerged from the data: Sense of Belonging to the University, and Sense of Belonging and ALC.

\section{Sense of Belonging to the University: Surveys}

The matching of 121 pre- and post-course responses revealed that, when asked if they felt like they belonged to the university, $69 \%$ of participants stated that they felt like they belonged to the university pre-course. Over the duration of the course, this percentage increased by $15 \%$ to $83 \%$. Open-ended, follow-up questions pre- and post-course provided insight into the factors behind the increase in sense of belonging. 
Open responses from the pre-course survey are analyzed and categorized in Figure 1. The question from which the data in Figure 1 were drawn was envisaged as an open response to give insight into the feelings of respondents who felt something other than belonging or not belonging to the academic community. In practice, 53 of the 121 students who responded "yes" or "no" to the previous question also responded to the follow-up question. ${ }^{4}$

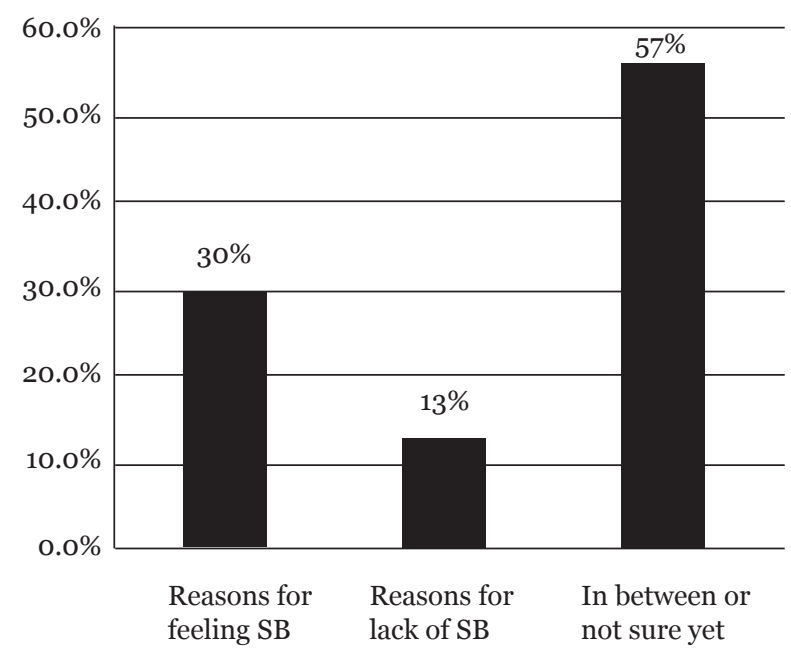

1. I like the school, and most importantly because I am a student here. All the staff here is helpful in dealing with my education related matters (SB)

2. It's a very diverse and open community. Everyone has a chance to do something or be a part of something important or of relevance to them (SB)

3. I sometimes don't feel like I belong here but because of my friends from high school, it's not too bad (no SB)

4. How are you supposed to make friends in a lecture hall??? I find that the only people I hang out are the people I knew before I started going here. (no SB)

5. I know little of these two words... hopefully I will understand it completely after the course (not sure yet)

6. It's only the first few days in PCU, so I don't really know the feeling. Sometimes I feel I belong to, but sometimes I also feel like isolated (not sure yet/in-between)

7. This is my second semester of the first year, so I feel like I do not know much about academic community (not sure yet)

8. It varies from time to time because it is such a big school and it is still new to me and I need a little more time getting use to this new environment. It is different than high school because I am learning with so many bright individuals (not sure yet/in-between)

Figure 1. Students' reports of SB (or lack of) before ALC and sample description ( $N$ - 53) 
Respondents 5, 6, 7, and 8 referred to sense of belonging as changing with time. For respondents 6 and 7, it was too soon to say. For respondent 8, "it varies from time to time," whereas respondent 5 expected better understanding after the course. Respondents 3, 4, and 8 cited interaction with new and old peers. Respondent 8 linked a sense of belonging to studying with brighter peers, whereas for respondents 3 and 4 , socializing with pre-university peers mitigated a lack of sense of belonging. Respondent 4 also referred to class size, suggesting that very large lecture classes are not conducive to developing sense of belonging. For respondent 1, interaction with helpful staff played a role in sense of belonging; respondent 2 stated that everyone has a chance to be part of something, implying that sense of belonging relates to individuals' conscious agency.

Open responses in the post-course follow-up question about university belonging are collated in Figure 2, in which 33 out of 236 respondents elaborated on their previous answers: $58 \%$ described reasons for their sense of belonging, $27 \%$ reasons for their lack of sense of belonging, and $15 \%$ a state between sense of belonging and lack of sense of belonging.

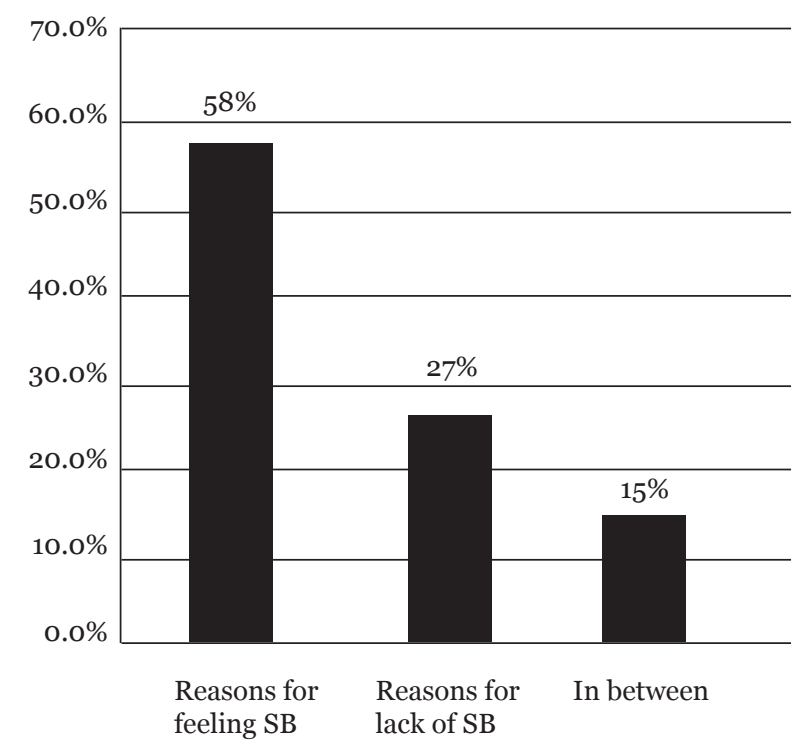

1. I feel like I am at everyones level. (SB)

2. The people that surrounds me makes me feel welcome (SB)

3. Professor and faculty really feel me welcome and belonged in any class that I tool. (SB)

4. The courses that I took this semester was manageable. Therefore, I feel quite comfortable. (SB)

5. I feel like other people do not take school as serious as me. (no SB)

6. I feel that it depends how much extra you have an dhow willing you are to "belong" (no SB)

7. I am in between feeling belong and not belong here because I feel fortunate to be able to study at PCU. At the same time, I am scare that I will not meet the GPA standard and will have to study at a collage to get back in (in-between).

8. I could not tell I like it or not because sometimes I feel comfortable and sometimes not comfortable. (in-between).

Figure 2. Students' reports of their SB (or lack of) after ALC and sample descriptions $(N=33)$ 
Respondents 1, 2, 3, and 5 referred to interpersonal relationships as key to their sense of belonging, or a lack of it: with peers $(1,2,5)$ and with instructors $(3)$. Respondent 6 described conscious agency and willingness as relating to lack of sense of belonging. Respondents 7 and 8 were in between: respondent 7 combined feeling grateful to be at the university with fears about falling below minimum GPA requirements; respondent 8 was divided between feeling comfortable and not. Finally, respondent 4 linked sense of belonging to a more practical factor: being able to manage course load.

\section{Sense of Belonging to the University: Interviews and Writing Samples}

Many of the above themes recurred in the qualitative data sets (interviews and writing samples), which were coded and categorized according to emerging themes. Data from interviews and writing samples are presented together under the three most common themes: culture of university belonging, belonging and space, and academic success.

Although participants were not asked in surveys to define or reflect on their understandings of the concept of sense of belonging, three participants in interviews gave responses that showed different conceptualizations of belonging to a university.

Julie: Belong to the school? I feel belong; it's no way I feel outside, yeah. I am proud being a PCU student.

Soreya: Definitely. It's a, it's a workout, but I mean it must be the same everywhere. The teachers are great. They're there to help you if you need help. If you don't understand something you can just go ask, and there's always advisers. Everybody's available.

Carme: I would say, "Not really." I guess that we never had this belonging into a school back home. It's never been "Wow! I'm from the University of Barcelona” ... It's just a tool for me. I've never been involved in any kind of aspect of that university meaning.

These three interview excerpts presented belonging to a university through different lenses. Julie felt a strong sense of pride and belonging, linking the university to personal identity. Soreya linked sense of belonging to overcoming challenges ("It's a, it's a workout") and to knowing people who can help. In contrast, Carme rejected the link between a university and sense of belonging, presenting the university as a tool for social progression, but not as something that would in any way define her sense of self or belonging.

The link between sense of belonging and spatiality, also referred to by Kostogriz and Tsolidis (2008), was mentioned by four participants. Descriptions included the following themes: friendships (or lack of them) in the post-secondary space, size of the campus, living in residence, and class size.

Tamsin: Maybe it's because of the people that, I don't know much people in PCU so maybe that is why I was feeling that I don't belong to PCU. Maybe in the future, once I get to know the school more, how to get around without getting lost.

Julie: For me because I have lived in residence so it's like a whole different story. 'Coz in residence, there is community, too. 
Tony wrote the following in his written reflection on "a major event in my life":

Moving into residence and meeting the floor mates can be a novel written in itself. There were people from all backgrounds and from many parts of the world. For the first week, we spent countless hours into the night just talking and drinking the happy juice. Luckily the floor bonded very quickly and has now become more like a family than anything else.

In George's written reflection on "a major event in my life," he also focused on campus life:

Before, I used to live at home with my parents but now I live on campus. People of different ages, some older and some younger than me, I'll have the opportunity to learn the ways each of them think on a particular idea.

In the data excerpts above, participants described their transition from secondary school/ home to the university at spatially determined interactional levels: transition to the physical space of the university and university residence, transition to new friendships in the unfamiliar space of the university, and transition from the fixity of home, family, and friends to the flux and fluidity of the new university environment.

Surprisingly, only one interviewee, Lisa, mentioned sense of belonging in terms of academic success:

I am starting to feel more belonging. Starting, but not exactly 'coz I am still worried about not being able to maintain my GPA, so that's the only worry that I have.

Lisa's emerging sense of belonging was conditional on her maintaining an adequate GPA to stay at the university. For students such as Lisa, falling below the 2.o (C grade) GPA average required to stay at PCU would result in academic probation and possibly the requirement to withdraw from the university. For Lisa, this factor appeared to override all others when it came to her sense of belonging at the university.

To sum up this section on participants' sense of belonging to the university, the quantitative and qualitative data on participants' sense of belonging to the university have revealed a broad range of factors. In surveys, some participants stated reasons for feeling a sense of belonging or not, whereas others were somewhere in between, unable to encode their perceptions in the yes/no format required by the researchers (Perry, 1992). The following factors stood out in surveys as related to participants' development of sense of belonging: willingness to adapt to the new university environment and new opportunities, the size of the university and class size, peer relations and making friends, and academic issues (relations with faculty, course load, and GPA concerns). In the data from interviews and writing samples, three themes recurred: the spatial aspects of finding a place and living on a large campus, the importance of making friends, and relations with faculty (and advisers). Interestingly, only one interviewee linked her sense of belonging to academic success, suggesting that students' sense of belonging can go far beyond their academic success. When academic success did relate to a sense of belonging, however, in the case of students who may be failing, then it had the potential to outweigh broader 
factors. Finally, two participants, Julie and Carme, questioned what belonging to an academic community meant as a concept, offering different cultural interpretations on the relationship between universities and individuals' sense of belonging. This factor may have been a result of the more intimate interview context in which participants were given more interactive space to question the researcher's constructs.

\section{Sense of Belonging and ALC: Surveys}

In this section, we present data related to sense of belonging and ALC from two perspectives: the extent to which ALC pedagogy and classroom experience were factors in students' development of a sense of belonging, and different levels of sense of belongingbelonging to ALC but not to the university, and vice versa.

To gauge the extent to which ALC pedagogy and classroom environment played a role in developing a sense of belonging, participants were asked the following question postcourse: "Has the ALC course helped you to feel a sense of belonging? Please answer 'yes' or "no'and explain why/why not." A total of 236 respondents answered the question, with $89 \%$ answering "yes" and 11\% "no." A summary of the course-specific reasons that the "yes" respondents gave in the follow-up open question is presented below in Figure 3 .

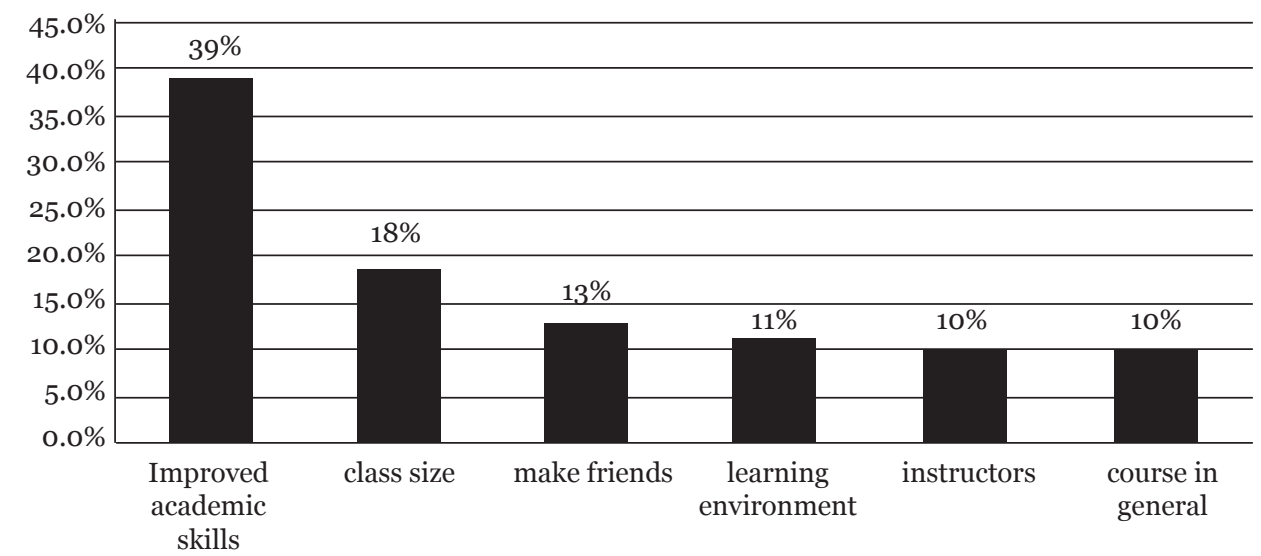

- 39\%: improved academic literacy - throughout the journey in this course. My belief in my English skills has been dramatically changed. Not only I learn about English usage, but also I find it easier and more comfortable to work with things related to English after building up more confidence in my English and speaking skills.

- 18\%: class size - Because small class size, everyone participates

- 13\%: make friends - I got to meet new people which helped with the process of being new at PCU.

- 11\%: learning environment - the small classes bring students together to provide a more comfortable learning environment

- 10\%: instructors - They made everyone feel included, from the advanced to the new. The teacher was great, the class I could do without.

- 10\%: course in general: - ALC course introduces what I need for university life and the expectations of professors.

Figure 3. Reasons why ALC helped respondents feel $S B(N=236)$ 
Figure 3 illustrates the important role that courses such as ALC can play in fostering a sense of belonging among students. The follow-up responses showed that the most important factor in developing a sense of belonging via the ALC classroom was improved academic literacy (39\%), which can help students to build their confidence in communicating in academic English. For students with English as an additional language, improved academic literacy and improved English were closely related. Other factors (small class size, new friends, learning environment, instructors, and the course in general) served together to create not only an environment in which students could improve academic literacy skills, but also one in which students felt welcome and safe in the classroom.

A summary of the reasons given by "no" respondents (11\%) is presented in Figure 4.

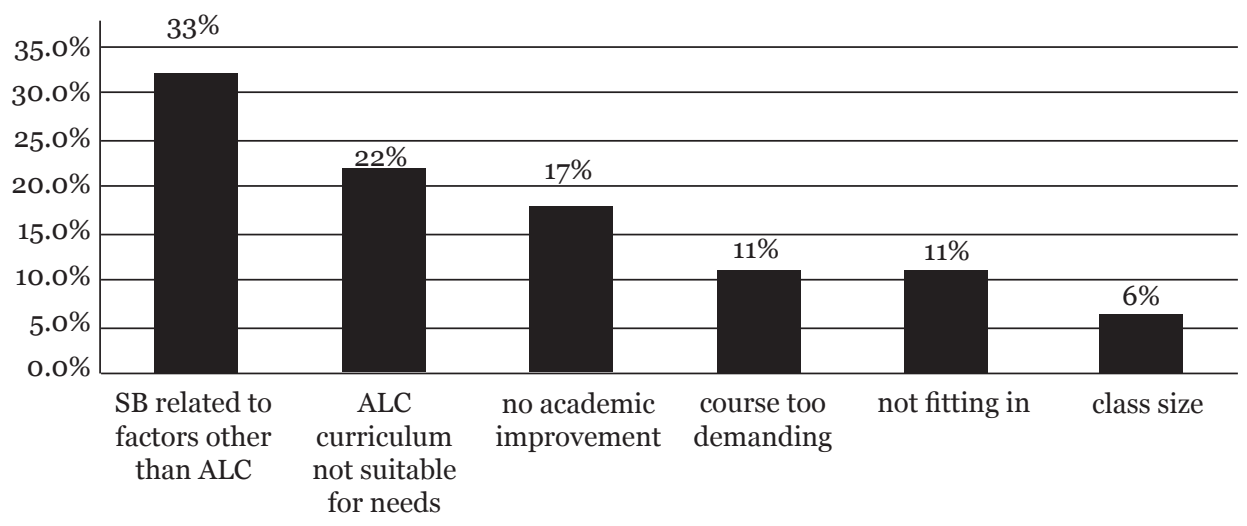

- 33\%: SB related to factors other than ALC - My involvement in ALC had nothing to do with my feeling of belonging. My feeling of belonging is completed exterior to ALC.

- 22\%: ALC curriculum not suitable for needs - The Course wasn't as intensive as I imagine it. I was expecting more work and more writing. I thought the ALC course is the shorter version of any W [writing-intensive] courses with the same intensively.

- 17\%: no academic improvement - It is similar with Eng 12. Although we had a lot of writing to do, the improvement of writing skills is not a lot.

- 11\%: course was too demanding - I don't have a sense of belonging because I don't feel I am involved... and I am too busy with school work.

- 11\%: not fitting in - I'm not sure the course helped me belong. It kept me busy with assignments. I feel that I should not have been placed in the course.

- 6\%: class size - because of the small size of the class, and most of the class split up into cultural groups pretty fast naturally.

Figure 4. Reasons why ALC did not help respondents feel $S B(N=236)$ 
A minority of respondents (11\%) felt that the course was not a factor in their sense of belonging, the most commonly stated reason being that their sense of belonging was related to factors outside of the course. Other factors were as follows: unsuitable curriculum, lack of improvement in academic literacy skills, the course being too demanding, not fitting in, and class size. Class size is of interest because it illustrated how one factor can be perceived by both "yes" and "no" respondents. In this case, the "no" respondents felt that the small class size exacerbated the cultural divisions in the class.

\section{Sense of Belonging and ALC: Interviews and Writing Samples}

In interviews, participants were asked if ALC had helped them to feel a sense of belonging. Data from interviews and writing samples are presented under the three most common themes: different levels of belonging (ALC not PCU, or PCU not ALC), class size, and ALC pedagogy.

During interviews, several participants described feeling a sense of belonging at different levels, namely, sense of belonging to the ALC course but not to the university, and vice versa.

Lisa: Yeah, I felt like I belong in that class. It's my class here at PCU. And, I knew where to go to when I need help ... but not within the whole PCU community.

Amy: Well, I just feel I belong to the ALC course [laughter] ... but not belonging in university, only for the ALC course.

Lisa and Amy revealed how a single course can garner a sense of belonging among novice university students. Amy did not specify reasons, whereas Lisa cited knowing that there was someone to whom she could go for help. In contrast, four participants described feeling a sense of belonging to the university but not to the course.

Marie: I don't think so. I think it's probably, probably because I didn't enjoy the course. I just didn't think I needed to take it ... Some of the things we did, it just seemed so, I don't know, I guess, I learned that in grade eight, type of thing.

Monique: It's not like I went into the class and was super comfortable with everyone, or people that I had things in common with other than Ellen. So in that sense, not really, no.

Ellen: Nobody else wanted to talk, right? And it just, it divided into the obvious cliques. There was, you, me, and Brad [a classmate], the Caucasians, and everybody else didn’t talk.

In Emi's written reflection in her portfolio introduction, she described a sense of not belonging based on being Canadian-born:

When I tried to register in English fiction, the program told me my English 12 mark did not meet the required mark and that I needed to take ALC. At the beginning of the semester I believed that I would not learn anything new in ALC. All I kept thinking was that I was born in Canada, lived in the same city for all my life and that I did not belong in this class. 
Neither Emi nor Marie felt that they should be in the course. Emi linked her lack of sense of belonging to being born in Canada, and Marie felt that she was going over old ground. Both Emi and Marie, Canadian-born native speakers of English, are also visually identifiable as being of East Asian ethnicity, studying in a class where most of the East Asian students are English-language learners. In this sense, a complex interplay between visual identification, national identity, and linguistic/literacy competence can come to the fore. Two white Canadian-born participants with English as a first language, Monique and Ellen, also based lack of belonging to ALC on a similar interplay. Both usually sat together in class with another white native speaker of English, separate from the 15 other students who were of Asian ethnicity. Both linked lack of sense of belonging to group dynamics which they described as linguistically and ethnically determined.

In the following responses, participants compared ALC classes, which are capped at 18 students, with large lecture classes that have hundreds of students:

Morris: In classes where there's a lecture with a hundred or more students, it's really hard to know people. It's actually the ALC course that's where I've known the most people.

Joseph: It was a small class. It was very social, unlike the other classes I was in.

Julie: It's difficult for first year students, it's so hard to make friends in the lecture hall.

Monique: So it was obvious that you wanted us to bond and make friends, but I don't think it was going to happen that easily ... when you're in bigger classrooms, like lecture halls, it, it's so much more comfortable to just start a conversation with someone because you know that you might not be sitting next to them next time.

George described large lecture halls in his written reflection on "a major event in my life":

There is one incredible experience at university that I've had for the first time in my life is that there are hundreds of people in the lectures; I was wondering how we learn and get to know everyone in the lectures.

Four participants above referred to the problems making friends in large lecture classes, with the exception of Monique, who regularly sat with two other white English-speaking students in her ALC class, and for whom the small ALC class size exacerbated her sense of not belonging.

Three participants referred to academic issues and specific ALC course content. George stated:

Like the way we learn in ALC courses; we are always in group, together, so that way I feel people around me, are very friendly.

In Amy's written reflection in her portfolio introduction, she linked literacy and confidence: 
Literacy serves as a fundamental basis to foster genuine understandings and mutual communication between people ... now I realize that my confidences of both expressing my own ideas as well as communicating with the others have been improved.

Also in a written reflection in a portfolio introduction, Monique describes the benefits of accepting constructive criticism from peers:

Peer review work has allowed me to be more open to constructive criticism. I used to receive criticism personally, but now I understand how valuable it is. I have gained a lot of confidence in writing, having others read my work.

In the above responses, competence in academic literacy and the ways in which ALC aims to foster this competence were mentioned indirectly in relation to building a sense of belonging, specifically, increased literacy competence for increased communication, confidence building through peer review, and general in-class interaction as a tool for dialogue and confidence building. We have implied that Monique's recognition (in her end-of-course portfolio) of the value of peer criticism and gaining confidence were indirectly related to her sense of belonging to the course. Of interest here is the apparent contradiction in this statement when compared to Monique's stated discomfort in the small class (in an interview), which we interpreted as relating to a lack of belonging. Although beyond the scope of this article, we noted that several participants saw their sense of belonging in different light in different contexts: at different stages (changing with time), via different data-gathering methods (surveys, interviews, writing samples), and in relation to whether or not belonging as a concept was stated explicitly (in the survey/interview questions) or not (in portfolios). From the perspectives of this study, we understand this apparent contradiction more in terms of illustrating how the conceptualization of sense of belonging was context-dependent and changes with time rather than in terms of a contradiction or lack of data validity as would be perhaps the case in a more quantitative study.

The survey and interview responses and writing samples in this section have shown the relation between the academic literacy course (ALC) and belonging. Most survey respondents (89\%) stated that the course had helped them to feel a sense of belonging. In the related open responses, the main reason stated was improved academic literacy, followed by several factors related to classroom environment and aspects of the course. The main reason for the "no" respondents was that their sense of belonging had nothing to do with ALC. Another significant factor was not fitting in (with the curriculum and other students). Class size was mentioned by "yes" and "no" respondents. Data from interviews and writing samples revealed different levels of belonging: to ALC and not PCU (students with English as an additional language) and vice versa (Canadian-born students with English as a first language). In addition, participants again cited class size (from both "yes" and "no" viewpoints) and how literacy competence and in-class activities led to increased confidence.

\section{DISCUSSION}

Through a mixed-method approach, combining surveys, interviews, and writing samples, we have presented a broad spectrum of data on the sense of belonging of students taking ALC, a first-year academic literacy course at Pacific Coast University. We sought 
answers to the following two research questions: What factors affect ALC students' sense of belonging during their first year of study? And, at what micro and macro levels, and in which contexts, do ALC students perceive (or not) sense of belonging? Surveys were employed to gain an understanding of the complex nature of the sense of belonging of 419 respondents. In interviews, survey questions were repeated and more open discussions ensued to reveal the multiple layers at which belonging is understood and performed in our participants' lives. Finally, writing samples were analyzed for written representations of existing and new themes of belonging. In this sense, the respective data sets served to inform each other by adding additional understanding of the multiple layers of belonging among ALC students.

A broad range of factors affected ALC students' sense of belonging both to the university and to the course. First, participants described their sense of belonging to the university as being affected by interacting with peers, making new friends, interacting with faculty and advisers, living in residence, and having a manageable course load. Those who described a lack of sense of belonging to the university linked it to two of these factors (interacting with peers and not making friends) as well as to the size of the campus and concerns about maintaining GPA. When participants described their sense of belonging in relation to ALC, they referred to improved academic literacy, small class size, new friendships, supportive learning environment, pedagogy, and instruction. Others perceived a lack of connection between their sense of belonging and ALC, stating that their sense of belonging was unrelated to the course. For those who referred to a lack of sense of belonging to ALC, the reasons they gave were a poor fit with curriculum and peers, lack of improvement in academic literacy, over-demanding course load, class size, linguistic difference, and national identity. Finally, a number of participants described a sense of being between belonging and not belonging, and uncertainty about their sense of belonging, citing the following factors: it was too soon to say, they were still finding their way around the large campus, and they had concerns about their academic success and GPA.

These findings represent a combination of factors that are both internal and external to the ALC classroom; however, our intention is not to emphasize the internal over the external, which Tinto (1997) has been critiqued for, or vice versa. Instead, we see a continuum between broader social contexts, the university, and the ALC classroom, along which internal and external factors are played out and become intertwined. For example, in-class participation and interaction, emphasized in Braxton et al. (2000), Campbell \& Li (2008), and Kostogriz \& Tsolidis (2008), were described by participants as affecting belonging in different ways. One such factor was interaction with classmates and forming new friendships in class; equally, we suggest that there exists an indirect relation between belonging and interacting with classmates in peer review activities, which allowed one participant, Monique, to learn to receive criticism and grow in confidence. However, other participants gave descriptions that linked belonging to relational factors that were external to both the ALC classroom and the university. For example, in terms of sense of belonging and developing friendships, some participants described maintaining friendships with friends from high school, outside the context of the course, as a factor that helped them to belong during the early stages of the transition to university. Making friends, therefore, is an important factor to consider in and outside the course. Moreover, much broader "external" sociolinguistic factors such as language, race, and nationhood 
were mentioned by participants as affecting their belonging in terms of developing inclass friendships, bringing together the macro and the micro. This interplay was seen when white English-speaking participants and Canadian-born participants of East Asian ethnicity mentioned language, race, and nationhood in interviews when talking about their interactions with peers within the ALC classroom. In this sense, our findings can build on the focus on minority students and ethnicity in studies by Hurtado and Carter (1997), Johnson et al. (2007), and Strayhorn (2008) as follows. First, we have illustrated that external factors such as language, race, and nationhood affected our participants' sense of belonging along a macro-micro continuum between the classroom, the university, and broader society. In this sense, we see the macro and micro not as mutually exclusive but as interrelated in complex interplays that change with context. Second, our findings revealed that the focus on minority students can also be understood through the lenses of majority students or those who are in some way between majority and minority: language, race, and nationhood were factors in the descriptions of participants' lack of inclass friendships (by two majority white English-speaking students) and lack of belonging (by two visible minority English-speaking students born in Canada).

Data from surveys, interviews, and participants' writing samples showed an increase in most participants' sense of belonging over the duration of the course. The data revealed multiple layers of belonging. Some participants felt a sense of belonging, others did not, and others were somewhere between the "yes" and "no" of belonging. Equally, some participants felt that they belonged to both the university and ALC, and others felt a sense of belonging to one but not the other. From these angles, our data revealed the sense of belonging to be a complex, multi-layered concept with many facets of perception. In other words, it is not always a "yes" or "no" construct; it was perceived at different micro and macro levels, and it changed with time and context. For students taking courses such as ALC, negotiating belonging through this multi-layered continuum formed a significant part of their first-year experience.

The most relevant contextual factor for participants in the study was perhaps that students from diverse backgrounds were sharing an academic space that carries an institutional identity of deficit and remediation, but which also required students to grow academically (Moores \& Popadiuk, 2011) in order to proceed with their studies. Again, improved academic literacy and language were the factors that most post-course survey respondents identified as contributing to their development of a sense of belonging. Notwithstanding, when students are positioned by institutional discourses as lacking, or having a deficit, it has inevitable consequences on their sense of belonging and on their perceptions of self-worth and legitimacy as university students (Marshall, 2010). Improving academic literacy is one way to overcome this positioning. However, for students required to take courses such as ALC, it is essential that they also develop a sense of belonging, both to the university and to the cohort of students with whom they study, if they are to gain a sense of legitimacy, which in turn can serve to foster self-esteem and the potential to succeed in higher education. It is imperative for courses such as ALC to focus not only on the academic literacy development of students, but also on students' perceptions of belonging, or not belonging, to the university. The pedagogy employed in ALC classrooms, therefore, included many activities that aimed to foster a sense of belonging and to recognize and respect the varied social, cultural, and linguistic backgrounds of students. 
One distinguishing feature of this study has been the analysis of students' written reflective narratives for issues related to belonging, texts that were written without specific reference to sense of belonging in their instructions. The writing samples were the result of a different form of knowledge co-construction, interaction, and intersubjectivity in which students reflected on their experiences in life and over the semester. In this sense, the selected data excerpts added another layer to data from surveys and interviews: three writers chose their transition to university as their major event and reflected on university life, from large impersonal lecture halls to a sense of community in residence. Others reflected on aspects of academic literacy and national identity as they wrote about their ALC experiences.

\section{IMPLICATIONS}

Our mixed-method approach did not aim for generalizability or triangulation. Bearing in mind the limitations stated earlier, we would like to highlight the findings that we feel educators involved in first-year courses such as ALC may want to consider. First, activities and pedagogies targeting ALC students' sense of belonging should not overplay lack of belonging, as many students may already feel a strong sense of belonging within institutions. In this regard, our data showed that $69 \%$ of ALC students described feeling a sense of belonging to the university at the beginning of the course, increasing to $83 \%$ at the end of the course. Second, those involved in drawing up policies, curricula, and events that focus on fostering belonging could consider the context-dependent, multi-layered nature of ALC students' sense of belonging. We found in our data that belonging can be uncertain, in between, or partial, and that a single factor can foster belonging in one student and not in another. Third, cultural and linguistic factors played an inevitable role in our participants' sense of belonging. Our findings suggest that cultural and linguistic factors became negative factors in sense of belonging when connected by participants to issues of Canadianness, language, and physical appearance. In ALC, therefore, instructors promote intercultural and interlinguistic understanding and tolerance among students, as well as across the university. In doing so, the aim is to challenge deficit views of diversity, views that only serve to entrench the discourses of remediation and lack of legitimacy that students in courses like ALC may perceive.

\section{CONCLUSION}

For our participants-students taking a required first-year academic literacy coursesome perceptions of belonging remain constant, whereas others change and evolve with time. Perceptions were manifested differently depending on the research methods in which knowledge was expressed, and they were co-constructed in different ways between the researcher and the researched. Our findings suggest that it may only be through creative and multiple research methods that the multiple layers and contexts of students' sense of belonging can be comprehensively revealed. As for how such perceptions change over time, further longitudinal study is needed, as is study into the extent to which our findings may lead to greater integration, retention, and success (Tinto, 1975).* 


\section{NOTES}

1. Pseudonyms are used for the names of institutions, courses, and individuals in this article.

2. We would like to thank the reviewers of this article for their recommendations and ideas, many of which have been incorporated into the article.

3. See Marshall (2010) for a detailed discussion of identity construction and institutional identities of deficit and remediation.

4. Data from surveys and interviews are presented in their original form without corrections to spelling, grammar, and punctuation. Some edits of phrases such as you know and like have been made in interview excerpts to improve readability.

\section{REFERENCES}

Andres, L., Andruske, C., \& Hawkey, C. (1996). Mapping the realities of first year post-secondary life: A study of students at three post-secondary institutions. Report prepared for the British Columbia Council on Admissions and Transfer.

Attinasi, L. C. (1989). Getting in: Mexican Americans' perceptions of university attendance and the implications for freshman year persistence. Journal of Higher Education, 60, 247-277.

Axelrod, P., \& Reid, J. G. (1989). Youth university and Canadian society: Essays on the social history of higher education. Kingston, ON: McGill-Queen's University Press.

Banks, J. A. (1993). The canon debate, knowledge construction, and multicultural education. Education Researcher, 22(5), 4-14.

Banks, J. A. (1995). The historical reconstruction of knowledge about race: Implications for transformative teaching. Education Researcher, 24(2), 15-25.

Banks, J. A. (1996). Transformative knowledge, curriculum reform, and action. In J.A. Banks (Ed.), Multicultural education, transformative knowledge, and action: Historical and contemporary perspectives (pp. 335-348). New York, NY: Teachers College Press.

Banks, J. A. (2002). Race, knowledge construction, and education in the USA: Lessons from history. Race, Ethnicity, and Education, 5(1), 7-27.

Baumeister, F. R., \& Leary, R. M. (1995). The need to belong: Desire for interpersonal attachments as a fundamental human motivation. Psychological Bulletin, 117(3), 497-529.

Bean, P. J., \& Metzner, S. B. (1985). A conceptual model of nontraditional undergraduate student attrition. Review of Educational Research, 55(4), 485-540.

Berger, J. B., \& Braxton, J. M. (1998). Revising Tinto's interactionalist theory of student departure through theory elaboration: Examining the role of organizational attributes in the persistence process. Research in Higher Education, 39(2), 103-120.

Bollen, K. A., \& Hoyle, H. R. (1990). Perceived cohesion: A conceptual and empirical examination. Social Forces, 69, 479-504.

Booker, C. K. (2006). School belonging and the African American adolescent: What do we know and where should we go? High School Journal, 89(4), 1-7. 
Bosetti, L., Kawalilak, C., \& Patterson, P. (2008). Betwixt and between: Academic women in transition. Canadian Journal of Higher Education, 38(2), 95-115.

Bourdieu, P. (1990). The logic of practice. Stanford, CA: Stanford University Press.

Bourdieu, P. (1991). Language and symbolic power (G. Raymond \& M. Adamson, Trans.). Cambridge, MA: Harvard University Press.

Braxton, M. J., Milem, F. J., \& Sullivan, S. A. (2000). The influence of active learning on the college student departure process: Toward a revision of Tinto's theory. Journal of Higher Education, 71(5), 569-590.

Bullivant, B. (1983). Multiculturalism: Pluralist orthodoxy or ethnic hegemony? Canadian Ethnic Studies/Études ethniques au Canada, 13(2), 1-22.

Campbell, J., \& Li, M. (2008). Asian students' voices: An empirical study of Asian students' learning experiences at a New Zealand university. Journal of Studies in International Education, 12(4), 375-396.

Clauss-Ehlers, C. S., \& Wibroski, C. R. (2007). Building educational resilience and social support: The effects of the educational opportunity fund program among first-and second-generation college students. Journal of College Student Development, 48(5), 574-584.

Codjoe, H. M. (2005). Africa(ns) in the Canadian educational system: An analysis of positionality and knowledge construction. In W. J. Tettey \& K. P. Puplampu (Eds.), The African diaspora in Canada: Negotiating identity and belonging (pp. 63-91). Calgary, AB: University of Calgary Press.

Cohen, L., Manion, L., \& Morrison, K. (2000). Research methods in education. London, England: Routledge Falmer.

Cummins, J. (1997). Minority status and schooling in Canada. Anthropology \& Education Quarterly, 28(3), 411-430.

Davies, P. (2000). Contributions from qualitative research. In H. T. Davies, M. N. Sandra, \& P. Smith (Eds.), What works? Evidence-based policy and practice in public services (pp. 291-316). Bristol, England: Policy Press.

Durkheim, E. (1951). Suicide: A study in sociology. New York, NY: Free Press.

Edwards, J. R. (1994). The study of congruence in organizational behavior research: Critique and a proposed alternative. Organizational Behavior and Human Decision Processes, 58, 51-100.

Freeman, T. M., Anderman, L. H., \& Jensen, J. M. (2007). Sense of belonging in college freshmen at the classroom and campus levels. Journal of Experimental Education, 75(3), 203-220.

Giddens, A. (1984). The constitution of society: Outline of the theory of structuration. Cambridge, England: Polity Press.

Goodenow, C. (1993). Classroom belonging among early adolescent students: Relationships to motivation and achievement. Journal of Early Adolescence, 13(1), 21-43. 
Hagerty, B. M., Williams, R. A., Coyne, J. C., \& Early, M. R. (1996). Sense of belonging as indicators of social and psychological functioning. Archives of Psychiatric Nursing, $10(4), 235-244$.

Hagerty, B. M., Williams, R. A., \& Oe, H. (2002). Childhood antecedents of adult sense of belonging. Journal of Clinical Psychology, 58(7), 793-801.

Hausman, L. R., Ward Schofield, J., \& Woods, R. L. (2007). Sense of belonging as a predictor of intentions to persist among African American and White first-year college students. Research in Higher Education, 48(7), 803-839.

Hoffman, M., Richmond, J., Morrow, J., \& Salomone, K. (2003). Investigating sense of belonging in first-year college students. Journal of College Student Retention, 4(3), 227-256.

Hurtado, S., \& Carter, D. F. (1997). Effects of college transition and perceptions of the campus racial climate on Latino college students' sense of belonging. Sociology of Education, 7o(4), 324-345.

Ivankova, V., Creswell, J. W., \& Stick, S. L. (2006). Using mixed-methods sequential explanatory design: From theory to practice. Field Methods, 18, 3-20.

Johnson, B. R., \& Onwuegbuzie, A. J. (2004). Mixed methods research: A research paradigm whose time has come. Educational Researcher, 33(7), 14-26.

Johnson, D. R., Soldner, M., Leonard, J. B., \& Alvarez, P. (2007). Sense of belonging among first-year undergraduates from different racial/ethnic groups. Journal of College Student Development, 48(5), 525-542.

Kember, D., Lee, K., \& Li, N. (2001). Cultivating a sense of belonging in part-time students. Journal of Lifelong Education, 2O(4), 326-341.

Kember, D., \& Leung, D. Y. P. (2004). Relationship between the employment of coping mechanisms and a sense of belonging for part-time students. Educational Psychology, 24(3), 345-357.

Kostogriz, A., \& Tsolidis, G. (2008). Transcultural literacy: Between the global and the local. Pedagogy, Culture \& Society, 16(2), 125-136.

Kvale, S. (1996). InterViews: An introduction to qualitative research interviewing. London, England: Sage.

Lehmann, W. (2007). I just didn't feel like I fit in: The role of habitus in university drop-out decisions. Canadian Journal of Higher Education, 37(2), 89-110.

Lyakhovetska, D. (2004). Welcome to Canada? The experiences of international graduate students at university. In L. Andres \& F. Finlay (Eds.), Student affairs: Experiencing higher education (pp. 189-216). Vancouver, BC: University of British Columbia Press.

Madgett, J. P., \& Belanger, H. C. (2008). First university experience and student retention factors. Canadian Journal of Higher Education, 38(3), 77-96.

Marker, M. (2004). The four Rs revisited: Some reflections on First Nations and higher education. In L. Andres \& F. Finlay (Eds.), Student affairs: Experiencing higher education (pp. 171-188). Vancouver, BC: University of British Columbia Press. 
Marshall, S. (2010). Re-becoming ESL: Multilingual university students and a deficit identity. Language and Education 24(1), 21-39.

McGee Thompson, D. (2004). A tunnel of hope: The experiences of student mothers attending a community -college-based developmental studies program. In L. Andres \& F. Finlay (Eds.), Student affairs: Experiencing higher education (pp. 65-91). Vancouver, BC: University of British Columbia Press.

Moores, L., \& Popadiuk, N. E. (2011). Positive aspects of international student transitions: A qualitative inquiry. Journal of College Student Development, 52(3), 291-306.

Ogbu, J. U. (1978). Minority education and caste. New York, NY: Academic Press.

Ogbu, J. U. (1992). Understanding cultural diversity and learning. Educational Researcher, 21(8), 5-14, 24.

Ostrove, J. M., \& Long, S. M. (2007). Social class and belonging: Implications for college adjustment. Review of Higher Education, 30(4), 363-387.

Pascarella, E. T., \& Terenzini, P. T. (1980). Predicting freshman persistence and voluntary dropout decisions from a theoretical model. Journal of Higher Education, 51(1), 60-75.

Perry, C. J. (1992). Problems and considerations in the valid assessment of personality disorders. American Journal of Psychiatry, 149, 1645-1653.

Read, B., Archer, L., \& Leathwood, C. (2003). Challenging cultures? Student conceptions of belonging and isolation at a post-1992 university. Studies in Higher Education, 28(3), 263-277.

Schuetze, G. H., \& Slowey, M. (2002). Participation and exclusion: A comparative analysis of non-traditional students and lifelong learners in higher education. Higher Education, 44(3), 309-327.

Sedgwick, M. G., \& Yonge, O. (2008). We're it, we're a team, we're family means a sense of belonging. Rural and Remote Health, 8(1021). Retrieved from http://www.rrh. org.au/articles/subviewnew.asp?ArticleID $=1021$

Spady, W. G. (1970). Dropouts from higher education: An interdisciplinary review and synthesis. Interchange, $1,64-85$.

Spady, W. G. (1971). Dropouts from higher education: Toward an empirical model. Interchange, 2, 38-62.

Steckler, A., McLeroy, K. R., Goodman, R. M., Bird, S. T., \& McCormick, L. (1992). Toward integrating qualitative and quantitative methods: An introduction. Health Education Quarterly, 19, 1-8.

Strayhorn, T. L. (2008). A hierarchical analysis predicting sense of belonging among Latino college students. Journal of Hispanic Higher Education, 7(4), 301-320.

Tinto, V. (1975). Drop-out from higher education: A theoretical synthesis of recent research. Review of Education Research, 45, 89-125.

Tinto, V. (1993). Leaving college: Rethinking the causes and cures of student attrition (2nd ed.). Chicago, IL: University of Chicago Press. 
Tinto, V. (1997). Classrooms as communities: Exploring the educational character of student persistence. Journal of Higher Education, 69, 599-623.

Tucker, E, J. (1999). Tinto's Model and Successful College Transitions. Journal of College Student Retention, 1(2), 163-175. Yorke, M. (2004). Retention, persistence and success in on-campus higher education, and their enhancement in open and distance learning. Open Learning, 19(1), 19-32.

Yum, J. C. K., Kember, D., \& Siaw, I. (2001). Coping mechanisms of part-time students. In D. Kember et al. (Eds.), Evaluation of the part-time student experience (pp. 101-116). Hong Kong: Open University of Hong Kong.

\section{CONTACT INFORMATION}

Steve Marshall

Faculty of Education

Simon Fraser University

888 University Drive

Burnaby BC V5A 1S6 Canada

stevem@sfu.ca

Steve Marshall is Assistant Professor in the Faculty of Education at Simon Fraser University. He researches academic literacy in higher education and the interplays between languages, migration, identities, and literacy. He is currently the Principal Investigator (with Co-Investigator Danièle Moore) for a qualitative, three-year, longitudinal study of the language practices and multiliteracies of multilingual first-year university students in Vancouver, Canada. The project is funded by the Social Sciences and Humanities Research Council of Canada.

Mingming Zhou is Assistant Professor in the Psychological Studies Academic Group, National Institute of Education, Nanyang Technological University (Singapore). She researches achievement motivation, academic emotion, and self-regulated learning, specifically, how learners monitor motivation, emotion, and the use of study tactics, and how they make decisions to adapt old tactics and invent new ones. Zhou and her colleagues have developed a web-based tracking tool that traces learners' problem-solving processes on the web. Her research has been published in leading international journals and books in educational psychology and technology.

Ted Gervan is the Curriculum Developer at the Vancouver Film School. He is responsible for overseeing curriculum and new program development, curriculum training, conducting needs analyses as well as curriculum policy development. Gervan is currently conducting research into non-traditional students' sense of belonging in a Canadian private post-secondary institution. Recently, Gervan and colleagues launched four innovative bachelor-level programs in the applied arts. 
Sunita Wiebe is Faculty Development Director/Academic Director at The Art Institute of Vancouver. She has over 18 years' teaching experience at the post-secondary level. Her doctoral thesis, which involved nearly 600 research participants, focused on first-year students and their instructors' conceptions of good academic writing. Her recent research interests have included learning-centred instruction, faculty development, student engagement, and composition pedagogy. She co-led a team that launched four applied degrees at The Art Institute of Vancouver and has designed numerous academic writing courses. Wiebe also researches students' sense of belonging and its impact on persistence at Canadian post-secondary institutions. 